ISSN: Print 2075 - 146X, Online 2616-6623. Витоки педагогічної майстерності. 2020. Випуск 25

Zayerkova, N. V. (2013). Kompleksna pidhotovka pedahohiv u systemi PPO shchodo formuvannya navychok spilkuvannya u vykhovantsiv spetsial'nykh shkil-internativ [Competence preparation of teachers in the system of postgraduate education for forming communicative skills of students of special schools and boarding schools]. Osvita na Luhanshchyni [Education in Luhansk region], 1, 131-136 [in Ukrainian].

BOYCHUK Y., KAZACHINER O.

H.S.Skovoroda Kharkiv National Pedagogical University, Ukraine

\title{
PREPARING FUTURE PROFESSIONALS FOR FORMING COMMUNICATIVE ACTIVITIES OF CHILDREN'S WITH SPECIAL EDUCATIONAL NEEDS
}

Most children with special educational needs have problems with interactionand communication. This is because for successful communication, the children must respond to other people when approached, and initiate communication on their own, and the quality of this process is impaired.

One of the conditions for the implementation of the New Ukrainian School concept, which states that for students with special needs the optimal conditions for learning together with their peers will be created, is the development of communication skills. In view of the above, there is an urgent need to properly train future professionals to undertake this activity.

During the research we used a set of the following methods: theoretical (analysis and synthesis of scientific-pedagogical literature, interpretation, modeling, concretization, etc.) and empirical (conversations, interviews, pedagogical observation, consulting, testing, etc.).

The purpose of the article is to disclose the content of our worked out discipline «Forming communicative activity of children with special educational needs» in the system of training of future specialists in specialty 016 «Special Education» at H.S. Skovoroda KhNPU.

The purpose of the study discipline is to prepare highly qualified, competitive, integrated specialist in the European and world scientific and educational space, who can qualitatively ensure the forming communication skills of children with special educational needs, as well as to promote harmonious development of personality adult / child with disabilities through different means.

The content of the program is presented: topics of lectures, questions and tasks for seminars, as well as a list of creative tasks for independent work. The program takes into account all aspects of communicative activity of different categories of children with special educational needs.

The results of the research can be used to develop new and improve the content of existing educational disciplines for the organization of education of children with SEN, aimed at training future specialists in the specialty 016 «Special Education» in institutions of higher pedagogical education.

Key words: future specialists, children with special educational needs, inclusive education, communication, communicative skills, forming communicative activity, New Ukrainian school

Стаття надійшла до редакції 14.07 .2020 р.

УДК 37.07:004

DOI: https://doi.org/10.33989/2075-146x.2020.25.223177

ОКСАНА БОЛЬШАЯ

ORCID: 0000-0003-0543-5196

Полтавський національний педагогічний університет імені В. Г. Короленка

\section{ІНФОРМАЦІЙНЕ ЗАБЕЗПЕЧЕННЯ ПРОЦЕСУ ПРИЙНЯТТЯ УПРАВЛІНСЬКИХ РІШЕНЬ У ЗАКЛАДАХ ОСВІТИ УКРАЇНИ}

У статті розглянуто функціонування інформаційного забезпечення та його вплив на управлінські рішення в закладах освіти. Обгрунтовується необхідність впровадження новітніх, сучасних інформаційних систем для удосконалення роботи менеджерів освіти.

Ключові слова: інформаційна система, інформація, менеджмент, управлінське рішення, освіта

Постановка проблеми та ії зв'язок із важливими науковими та практичними завданнями. Сучасний розвиток системи освіти України перебуває у стадії становлення та реформування. Ті виклики, які постали перед менеджерами освіти сьогодні, потребують кардинальних змін у системі управління. Адже від зміни методів, засобів і механізмів та від ефективності управління залежить динаміка розвитку системи освіти загалом. Впровадження та використання новітніх інформаційних систем у менеджменті освіти є необхідною умовою для підвищення його ефективності. 
Аналіз останніх досліджень і публікацій. Теоретичні та практичні аспекти використання інформаційних систем у менеджменті розкривають праці таких учених, як О. Анісімов, С. Богомазов, Н. Бусленко, В. Василенко, В. Вітлінський, В. Глушков, В. Гужва, Р. Калюжний та інші. Науковці, зокрема, приділяють чималу увагу проблемі впливу інформаційного забезпечення на процес прийняття управлінських рішень.

Метою статті є обгрунтування необхідності вдосконалення процесів прийняття управлінських рішень у закладах освіти на основі новітніх інформаційних технологій.

Виклад основного матеріалу дослідження. Впровадження та використання новітніх інформаційних систем у діяльності закладів освіти є необхідною умовою підвищення ефективності праці. Створення та розвиток інформаційного забезпечення для якісної роботи менеджерів освіти - це одне з головних завдань сьогодення, адже найважливіший фактор підвищення ефективності праці у структурі $є$ поліпшення управління. Удосконалення методів і форм управління відбувається на основі досягнень науково-технічного прогресу та подальшого розвитку IT-науки. Діяльність закладів освіти неможлива без використання інформації, яка виступає першорядним фактором для продуктивної роботи та прийняття правильних рішень менеджерами. Велике значення для процесу має науковотехнічна інформація при прийнятті рішень, яка містить нові наукові знання. Інформація $є$ основою для певної аналітичної та звітної роботи, несе пропозиції для певної розробки і прийняття управлінських рішень.

Управлінські рішення акумулюють в собі свідому і цілеспрямовану діяльність, яка є не повною без застосування інформаційного забезпечення. Інформаційне забезпечення акумулює в собі систему в собі пошук необхідної інформації, оцінку отриманої інформації, зберігання та подальше використання. Управлінська діяльність керівника освітнього закладу має бути спрямована на узгодження всіх дій суб'єктів управління, що гарантує забезпечення раціонального досягнення навчальної мети. Інформатизація управління навчальним закладом потребує розробки організаційної структури інформаційної системи управління навчальним закладом та технології ії впровадження. Застосування інформаційних технологій в управлінні освітнім закладом дає змогу забезпечити: вчасне подання оперативної інформації працівнику, який приймає рішення, 3 урахуванням його характеру; вчасне надання аналітичної інформації; надання оптимального обсягу інформації з вірогідністю не нижче допустимого рівня; надання рекомендацій за вибором рішень та скорочення тривалості процесу вироблення рішення, можливість навчання «без відриву від виробництва» тощо (Вербовський, 2015). Тому виникає дедалі більша потреба у створенні системи форм роботи та відповідних їм програмно-апаратних засобів, які забезпечували б підтримку й управління всім комплексом процесів, пов'язаних 3 ефективним функціонуванням органів управління та структур, що організують і здійснюють підготовку та підвищення кваліфікації науково-педагогічних і педагогічних кадрів (Вербовський, 2015).

Головною метою управління є досягнення певних, визначених цілей, які реалізуються через процес прийняття і виконання управлінських рішень. Управлінські рішення розробляються та реалізуються через багатосторонній організаційний та інтелектуальний процес між членами певної структури чи організації, базуючись на застосуванні різних методів, способів та моделей збереження, відтворення та використанні інформації та інформаційного забезпечення.

Інформаційні системи управління поєднують в собі компоненти, які визначають різні аспекти інформаційної діяльності об'єкта. Інформація для ланок управління та суб'єктів є різною і визначається певними завданнями та потребами з якими зустрічається менеджер у процесі управління. Інформація залежить від масштабу та важливості прийняття того чи іншого управлінського рішення, від величини та різноманітності впливу на підпорядковану систему та кількості підлеглих, кількості та якості показників функціонування певної системи.

Для створення та безперебійного функціонування інформаційної системи в закладах освіти при прийнятті управлінських рішень необхідно визначити іiї об'єкт, зміст та джерела, сформувати потоки інформації та розділити їх на необхідні рівні зберігання та використання. Головною метою створення єдиної інформаційної системи в управлінні закладом освіти - є іiі повне використання при безпосередній взаємодії між усіма суб'єктами та об’єктами робочого процесу. Головним завданням інформаційної системи є надання швидкої та правдивої інформації по тому чи іншому питанню для прийняття виваженого, всебічно обгрунтованого управлінського рішення.

У процесі управління головним завданням інформації є зниження рівня невизначеності, бо саме інформація дозволяє впорядкувати господарські процеси та узгодити їх із зовнішнім середовищем і внутрішніми потребами підприємства. При зниженні рівня або усуненні невизначеності інформація визначає стратегію підприємства та способи досягнення встановлених на підприємстві цілей (Кондратюк, 2013).

Сьогодні управління вимагає нових підходів до використання та обслуговування інформації, застосування методів аналізу та оптимізації напрямів зовнішніх і внутрішніх інформаційних процесів. Продуктивність інформаційного процесу збільшується за умови зростання його швидкості, кількості користувачів, цільової істотності, затребуваності бізнес-процесів, розгалуження при мінімальному часі передавання при одночасному зниженні втрат у процесі переміщення інформації, іiі оновленні на етапі переміщення (у разі об'єктивної необхідності). Таким чином, необхідність використання інформаційного процесу грунтується на теорії «інформаційного вибуху», згідно до якої кількість інформації, доступної суспільству, збільшується, що веде до якісної зміни середовища - інформаційного управління (Щербак, 2018).

Сучасний етап розвитку інформаційного забезпечення управління закладами освіти відповідає таким тенденціям: відбувається збільшення обсягу та покращення якості інформаційних ресурсів; покращення технічних характеристик обладнання, яке вдосконалюється завдяки технологічному прогресу; якісне оновлення спеціалізованих програмних продуктів, що покращують роботу менеджерів освіти.

Для вирішення та покращення роботи управлінці проходять певні етапи своєї роботи. На початковому етапі менеджер розпочинає підготовку управлінського рішення, яке включає в себе визначення мети та цілі, збирає та аналізує певну інформацію по тому питанню, яке необхідно вирішити. Прогнозує усі можливі варіанти кінцевих 
результатів під час прийняття управлінських рішень і, як наслідок, вибирає найефективніші і результативні варіанти.

Наступний етап управлінського рішення полягає у прийнятті та реалізації. Іде вибір певного найкращого варіанту, ведеться розробка плану реалізації цього рішення та контроль за його виконанням. Кінцевим етапом $\epsilon$ оцінка та відповідність управлінського рішення поставленій на початку меті.

Тобто, спираючись на такий умовний поділ реалізації управлінського рішення, менеджер освіти зобов'язаний використовувати і аналізувати великий обсяг інформації. Для більшого розуміння цього процесу необхідно дати визначення поняттю «інформація» (від лат. informatio - уявлення, поняття про будь-що) відомості, які передаються людьми в усній, письмовій формах або іншими засобами (за допомогою умовних сигналів, технічних засобів та ін.). Можна зробити висновок, що з точки зору права, інформація - це знакові комбінації у формі відомостей та/або даних, що є об'єктами публічного або приватного інтересу. Це визначення об'єднує у собі такі особливості: закріплює, що інформація має знакову форму, що охоплює всеосяжність форм фіксації та передачі інформації у людському суспільстві; підтверджує, що інформація має сенс, є цінною та корисною; не має прив'язки до обов'язкової здатності бути закріпленою на матеріальному носії або відображеною в електронній формі, що сьогодні є недоречним, адже, по-перше, не можливо і не потрібно встановлювати вичерпний перелік форм зберігання та способів передачі інформації (науково-технічний розвиток постійно відкриває нові можливості), а, подруге, ця прив'язка є недоцільною, обмежуючою; крім того, дані вже передбачають технічний пристрій для їх запису, зберігання, передачі та обробки, а сприймання відомостей сенсорною системою людини, безумовно передбачає можливість їх фіксації на придатному носії); враховує поділ на ієрархічні рівні інформації, зокрема, поняття відповідає державному рівню, має державно-правовий характер та відображає інформацію, як об'єкт суспільних відносин, що потребує правового захисту (Харенко, 2014).

Інформаційне забезпечення процесу підготовки та реалізації управлінських рішень стає основою при їній реалізації. Це сукупність єдиної системи класифікацій та кодування техніко-економічної інформації, уніфікованої системи документації організації, яка забезпечується технічними засобами. Основою інформаційного забезпечення при розробці та реалізації управлінських рішень є інформаційні ресурси та проведення інформаційно-аналітичної роботи. Інформаційне забезпечення акумулює надходження та обробку інформації, що включає в себе всі дані, методи їх кодування, зберігання та передавання.

Інформаційні технології сфери управління надають менеджерам освіти ефективний та потужний механізм для виконання таких видів діяльності: інформаційно-аналітичної, організаційно-розпорядчої, планово-прогностичної, контрольно-діагностичної, корекційно-регулятивної.

Ключовими компетенціями, якими мають володіти менеджери освіти є інформаційна та аналітична. Так, інформаційну компетенцію розглядають як здатність побудови ефективної системи інформаційних ресурсів, необхідної для формування інформаційно-правової основи прийняття управлінських рішень; здатність визначення затребування певного інформаційного ресурсу в межах оперативного та стратегічного управління організацією. Відповідно до аналітичної компетенції віднесено: здатність обумовленої оцінки ефективності запропонованої для використання системи інформаційних ресурсів; здатність об'єктивної оцінки позитивних та негативних аспектів кожного компоненту системи інформаційних ресурсів; здатність здійснення оперативної аналітичної оцінки інформаційних потоків, отриманих від кожного компоненту інформаційної системи; уміння оперативно й ефективно здійснювати аналітичне співставлення інформаційних потоків, що виходять від кожного компонента системи інформаційних ресурсів; здатність формулювання на основі отриманої інформації комплексних аналітичних висновків; здатність інтерпретувати, систематизувати, критично оцінювати і використовувати отриману інформацію в контексті вирішуваного управлінського завдання або проблеми (Ерсьозоглу, 2014).

Комунікаційна техніка та телекомунікаційні мережі, банки і бази даних та наукової, навчальної інформації, інформаційно-аналітичні центри різного рівня, технічні засоби інформатизації та висококваліфіковані менеджери та інші фахівці освітнього простору - це основні чинники якісної та продуктивної роботи системи в цілому. Використання IT-технологій у щоденній роботі менеджерів освіти дає можливість їм своєчасного отримання оперативної та аналітичної інформації, оптимального надання обсягу інформації, отримання необхідних рекомендацій при підготовці рішень та скорочення терміну прийняття управлінського рішення в часі.

Невід'ємною складовою інформаційного забезпечення роботи менеджера $є$ розробка та використання програмного забезпечення. Програми, які використовуються поділяються на такі види: навчальні, діагностичні, тренувальні, імітаційні, моделюючі, інструментальні. Інформаційна складова процесу управління є надзвичайно важливою, адже жоден процес без використання необхідної інформації не може здійснюватися. Для управлінця надзвичайно важливо використовувати достовірну, вичерпну інформацію для ефективного результату. Тільки достовірне знання щодо якісних змін у процесах навчання, виховання, методичного та матеріально-технічного їх забезпечення, інформація по результатам діяльності педагогічних кадрів, безперебійне функціонування всіх структурних підрозділів навчального закладу дає змогу приймати обгрунтовані рішення, відповідні їх потребам та корегувати і регулювати умови, які необхідні для ефективної роботи колективу.

Впровадження та використання інформаційно-комунікаційних технологій в управлінні закладом освіти має такі позитивні результати: підвищує ефективність процесу навчання, прийнятті ефективних управлінських рішень, можливість аналізувати та використовувати попередній досвід управління, підвищення об'єктивності при оцінюванні діяльності усіх учасників навчального процесу, оперативний доступ до організаційної інформації закладу освіти; економія матеріальних і людських ресурсів (Пересечанський, 2016).

Інформаційна складова управління допомагає покращити організацію праці менеджера освітнього закладу. Відбувається впровадження автоматизованої обробки та обліку інформації, а також удосконалення системи ведення документації. Покращується інформаційна взаємодія між відповідними рівнями системи управління та використання новітніх засобів зв'язку, що веде, в свою чергу, до зменшення паперового обігу і збільшення обміну 
інформацією в електронному вигляді. Програмні продукти, які створюються для покращення управління закладами освіти допомагають швидко знаходити необхідну інформую про учнів та співробітників, оперативне датування навчальних планів та ведення електронних журналів, автоматичне формування різного плану звітів, моніторинг якості навчання на всіх рівнях навчального процесу.

Керівники сучасної освіти потребують аналізувати великі за обсягом матеріали, уміння узагальнювати тенденції, робити прогноз розвитку педагогічної системи та, приймати рішення, виконувати їх, оцінювати результати. Шкільний сайт у комплексі із іншими заходами 3 інформатизації навчального закладу частково вирішує $\mathrm{i}$ управлінські процеси, які не обмежуються внутрішньошкільним управлінням; посилюють вплив соціуму, громадськості на управлінську діяльність; управляють людськими ресурсами, залучають педагогів, батьків, учнів до вирішення шкільних проблем. Практичне використання новітніх програмних продуктів у системі дозволяє зробити процес управління навчальним закладом більш ефективним та інтенсивним, коли використовуються системи автоматичного створення та ведення веб-журналів; системи вікі-енциклопедій; системи збереження мультимедійних веб-ресурсів; системи створення ньюс-порталів, призначених для висвітлення подій, що відбуваються в навчальному закладі, а також для анонсів, оголошень, тощо. Широкі можливості розвитку інформаційних систем, систем зв'язку ведуть до становлення інформаційного суспільства, що призводить до висування вимог до освіти молоді 3 урахуванням попередніх досягнень і до виникнення перспектив розвитку техніки і технології. Використання комп'ютера як управлінського, інформаційного, навчального та контролюючого технічного засобу сприяє вдосконаленню традиційних методик управління навчальним закладом (Алєксєєва, 2017).

Використання інформаційної діяльності менеджером освітнього закладу базується за такими принципами: у структурі ресурсів інформаційної діяльності значне місце посідають нематеріальні активи, інформація; ключову роль в організації інформаційної діяльності, зокрема й для встановлення порядку використання всіх ресурсів, відіграють вимоги/потреби споживачів інформації; визначення якісних характеристик інформації значною мірою має суб'єктивний характер; для ефективної організації інформаційної діяльності особливе значення має кваліфікація кадрів; можливості формування запасів «готової продукції» у формі інформації, «придатної до використання», обмежені, як правило, жорсткими рамками часу через швидке «старіння» інформації (Вербовський, 2015).

Важливою умовою ефективного застосування інформаційного забезпечення при прийнятті управлінських рішень $\epsilon$ акумулювання інформації щодо стану роботи закладу освіти та перспектив його розвитку. Так як технології розвиваються та вдосконалюються дуже швидко, менеджер має підвищувати свою кваліфікацію та постійно покращувати свої знання, задля ефективної управлінської роботи.

Висновки з дослідження і перспективи подальших розвідок у даному напрямі. Інформаційне забезпечення в управлінській діяльності менеджерів освітнього закладу є надзвичайно важливим. На сьогодні неодмінною умовою успіху в управлінні та продуктивній роботі $\epsilon$ вміння використання новітніх інформаційно-комунікаційних технологій, що дає можливість підвищувати рівень якості та ефективності навчального процесу, зменшити час на виконання покладених завдань усіма структурними підрозділами навчального закладу, можливість отримання оперативного доступу до інформації щодо діяльності навчального закладу.

Отже, інформатизація начального закладу $є$ невід'ємним компонентом якісного процесу управління менеджером. Використання інформаційно-аналітичної діяльності, що складається з сукупності дій на основі збору, накопичення, обробки та проведення аналітичної роботи дає можливість приймати обгрунтовані та правильні рішення щодо роботи навчального закладу, а це є головною умовою прогресивного функціонування.

\section{Список використаних джерел}

Алєксєєва, Г. (2017). Практичні аспекти використання сучасних освітніх технологій в управлінні навчальним закладом. Взято з htpp://www.researchgate.net

Вербовський, I. (2015). Інформатизачія управління навчальним закладом як один зі шляхів підвищення ефективності освітньої діяльності. Взято з htpp:// www.magazine.mdpu.org.ua

Ерсьозоглу, I. (2014). Інформаиійно-аналітична діяльність освіти шкільного рівня. Взято з htpp://www.irbis-nbuv.gov.ua Кондратюк, О. (2013). Вплив ризиків на господарську діяльність підприємства. Взято з htpp://www.irbis-nbuv.gov.ua

Пересечанський, В. (2016). Інформаційне забезпечення управлінської діяльності керівника закладу освіти. Взято 3 htpp://www.tme.umo.edu.ua

Харенко, О. (2014). Поняття «інформаиія» в юридичній науиі та в законодавстві Украӥни. Взято з htpp://www.irbisnbuv.gov.ua

Щербак, А. (2018). Сутність інформаційних проиесів промислового підприємства. Взято htpp://www.repository.hneu.edu.ua/bitstream/123456789/19744/1/Sherbak.pdf 


\section{References}

Alieksieieva, H. (2017). Praktychni aspekty vykorystannia suchasnykh osvitnikh tekhnolohii v upravlinni navchalnym zakladom [Practical aspects of the use of modern educational technologies in the management of an educational institution]. Retrieved from htpp://www.researchgate.net [in Ukrainian].

Ersozohlu, I. (2014). Informatsiino-analitychna diialnist osvity shkilnoho rivnia [Information and analytical activities of school level education]. Retrieved from htpp://www.irbis-nbuv.gov.ua [in Ukrainian].

Kondratiuk, O. (2013). Vplyv ryzykiv na hospodarsku diialnist pidpryiemstva [The impact of risks on the economic activity of the enterprise]. Retrieved from htpp://www.irbis-nbuv.gov.ua [in Ukrainian].

Kharenko, O. (2014). Poniattia "informatsiia" v yurydychnii nautsi ta v zakonodavstvi Ukrainy [The concept of "information" in legal science and legislation of Ukraine]. Retrieved from htpp://www.irbis-nbuv.gov.ua [in Ukrainian].

Peresechanskyi, V. (2016). Informatsiine zabezpechennia upravlinskoi diialnosti kerivnyka zakladu osvity [Information support of managerial activity of the head of the educational institution]. Retrieved from htpp://www.tme.umo.edu.ua [in Ukrainian].

Shcherbak, A. (2018). Sutnist informatsiinykh protsesiv promyslovoho pidpryiemstva [The essence of information processes of an industrial enterprise]. Retrieved from htpp://www.repository.hneu.edu.ua/bitstream/123456789/19744/1/Sherbak.pdf [in Ukrainian].

Verbovskyi, I. (2015). Informatyzatsiia upravlinnia navchalnym zakladom yak odyn zi shliakhiv pidvyshchennia efektyvnosti osvitnoi diialnosti [Informatization of educational institution management as one of the ways to increase the efficiency of educational activities]. Retrieved from htpp:// www.magazine.mdpu.org.ua [in Ukrainian].

\section{BOLSHAIA O.}

Poltava V. G. Korolenko national pedagogical University, Ukraine

\section{INFORMATION SUPPORT OF THE PROCESS OF MAKING MANAGERIAL DECISIONS IN EDUCATIONAL INSTITUTIONS OF UKRAINE}

The article considers the functioning of information support and its impact on management decisions in educational institutions. The necessity of introduction of the newest, modern information systems for improvement of work of managers of education is proved.

The opinion is substantiated that information support in the managerial activity of educational institution managers is extremely important. Today, a prerequisite for success in management and productive work is the ability to use the latest information and communication technologies, which allows to increase the quality and efficiency of the educational process, reduce time to perform tasks by all departments of the institution, the ability to quickly access information on activities educational institution. It is concluded that the informatization of the primary school is an integral component of a quality management process. The use of information-analytical activities, consisting of a set of actions based on the collection, accumulation, processing and conduct of analytical work makes it possible to make informed and correct decisions about the work of the institution, and this is the main condition for progressive operation.

Key words: information system, information, management, management decision, education

Стаття надійшла до редакції 11.08 .2020 p. 